\title{
円弧切欠き弾性ヒンジの変形特性に関する数値的検討 \\ A Numerical Examination of Angular Deflection Feature of Flexure Hinges with Circular Cutouts
}

\author{
正 O賀勢 晋司（信州大）＼cjkstart畠山 拓弥（日本精工）＼cjkstart水間 敬太（TOWA）
}

Shinji KASEI, Shinshu University, Wakasato 4-17-1, Nagano

Takuya HATAKEYAMA, NSK Ltd.

Keita MIZUMA, TOWA Corp.

Key Words: Flexure Hinge, Angular Deflection Feature, Numerical Examination, Paros's Equation, FEM

\section{1. 緒 言}

弾性ヒンジは通常, 部材に円弧状切欠き（みぞ）を設けた もので，精密あるいは超精密機構における力（モーメント） 一変位変換用の要素として, 微動案内部などに欠くことがで きない部品となっている。その設計においては，力（モーメ ント）と変位の間の変位特性, すなわちばね定数を知る必要 があり，パロス等の式 (J. M. Paros and L. Weisbord ${ }^{(1)}$ ) がその 近似式としてよく利用されている。

しかし，このパロスの式について，その導き方やヒンジ形 状に伴う近似度がどのようなものであるか，必ずしも知られ ているとは言えない。

そのため本報では, 円弧状切欠きヒンジのばね定数につい て材料力学的な一般的理論式を求め, 上述の近似度の検討結 果を報告する。なお，長方形断面部材に対する両側及び片側 切欠き, 円形断面部材に対する環状切欠きの形態を検討対象 とし, 有限要素計算結果も取り入れる。

\section{2. ばね定数の解析}

先ず，両側切欠き形の場合を考え，図 1 (a)にその形状と記 号を示す。切欠きによるくびれ部分だけが変形に関係すると し, 曲げモーメント $M$ によるたわみ角 $\alpha$ を求める。たわみ $Y$, 縦弾性係数 $E$, 断面 2 次モーメント $I_{\mathrm{D}}$ を用いれば,

$$
\alpha=\frac{d Y}{d x}=\int_{x_{0}}^{x_{0}} \frac{M}{E I_{D}} d x
$$

ただし $, x_{0}=R \sin \theta_{m}, \quad I_{D}=(2 / 3) b_{D} y^{3}$ である。

変数変換により, 式(1)の被積分関数を $\left(a_{2} s^{2}+a_{1} s+a_{0}\right)$ を 含む形に変え, 積分を進め ${ }^{(2)}$, ばね定数 $K_{1}$ が明らかになるよ うにその結果を整理すると，

$$
\begin{aligned}
\frac{1}{K_{1}} & =\frac{\alpha}{M} \\
& =\frac{3}{2 E b_{D} R^{2}}\left(\frac{1}{2 \beta+\beta^{2}}\right)\left[\left\{\frac{1+\beta}{\gamma^{2}}+\frac{\beta^{2}+2 \beta+3}{\gamma\left(2 \beta+\beta^{2}\right)}\right\}\right. \\
& \left.\cdot \sqrt{1-(1+\beta-\gamma)^{2}}+\left\{\frac{3(1+\beta)}{\left(\beta^{2}+2 \beta\right)^{3 / 2}}\right\} A\right]
\end{aligned}
$$

なお,

$A=\tan ^{-1} \frac{1+\sin \theta_{m}-B \cos \theta_{m}}{\sqrt{1-B^{2}} \cos \theta_{m}}-\tan ^{-1} \frac{\cos \theta_{m}-B\left(1+\sin \theta_{m}\right)}{\sqrt{1-B^{2}}\left(1+\sin \theta_{m}\right)}$
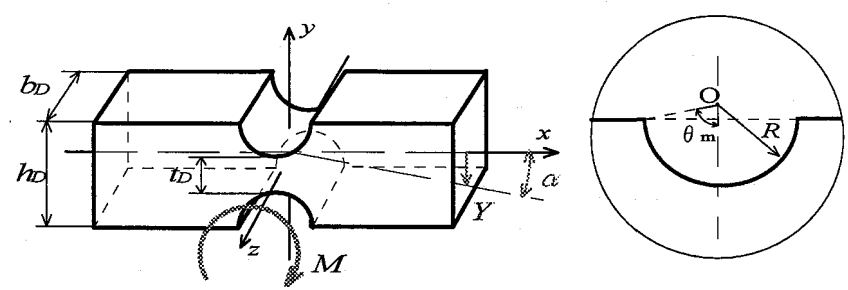

(a) Both sides cutouts

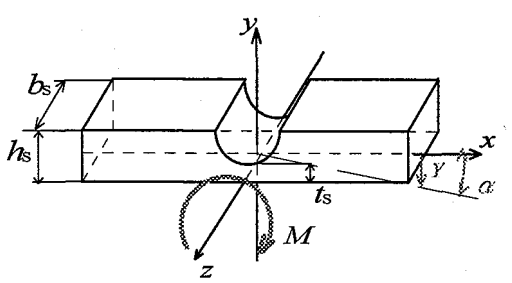

(b) One side cutout

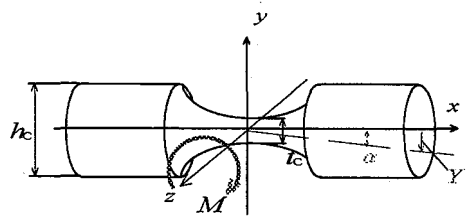

(c) Circular cutout

Fig. 1 Three kinds of hinge and dimensional symbols

ここで, パラメータとして $, \beta=t_{\mathrm{D}} /(2 R), \quad \gamma=h_{\mathrm{D}} /(2 R), \quad B=$ $2 R /\left(2 R+t_{\mathrm{D}}\right)$ とする。図 1 の右上に円弧状切欠きの形状と記号 を示す。 $R$ は円弧半径, $\theta_{\mathrm{m}}$ は円弧中心 $\mathrm{O}$ から見た円弧半角を 表す。これらは片側切欠きと環状切欠きの場合にも同様に用 いる。

両側切欠きの場合, パロス等の式(1)によるばね定数 $K_{1 \mathrm{P}}$ は,

$$
\frac{1}{K_{1 P}}=\frac{9 \pi}{2 E b_{D} R^{2}(2 \beta)^{5 / 2}}=\frac{9 \pi R^{1 / 2}}{2 E b_{D} t_{D}^{5 / 2}}
$$

と表される。式(2)において， $\beta \leqq 1, \beta \leqq \gamma$ ，それに伴っ $\tau \gamma \rightarrow 1, \mathrm{~B} \rightarrow 1, \theta_{\mathrm{m}} \rightarrow \pi / 2$ とし, 次のような近似的扱いをし てみる。

$$
\begin{aligned}
\frac{1}{K_{1}} & \approx \frac{3}{2 E b_{D} R^{2}} \cdot \frac{1}{2 \beta}\left\{\left(1+\frac{3}{2 \beta}\right)+\frac{3}{(2 \beta)^{3 / 2}}\left(\frac{\pi}{2}+\frac{\pi}{2}\right)\right\} \\
& =\frac{3}{2 E b_{D} R^{2}}\left\{\frac{1}{2 \beta}+\frac{3}{(2 \beta)^{2}}+\frac{3 \pi}{(2 \beta)^{5 / 2}}\right\}
\end{aligned}
$$


$\beta$ が十分小さければ，上式右辺の中括弧内の第 1 及び第 2 項 は第 3 項に較べてかなり小さいと思料されるので，それらを 無視すれば, 式(3)が導かれる。式(3)には, 以上のような取 り扱い方が含まれているのではないかと思う。

次に, 図 1 (b)の片側切欠きの場合を同様な考え方で解き， ばね定数 $K_{2}$ を導く。その結果から，ばね定数のパロス流の 近似值 $K_{2 \mathrm{P}}$ が次のように求められる。

$$
\frac{1}{K_{2 P}}=\frac{36 \pi}{E b_{S} R^{2}(2 \beta)^{5 / 2}}=\frac{9 \pi R^{1 / 2}}{\sqrt{2} E b_{S} t_{S}{ }^{5 / 2}}
$$

図 1 (c)の環状切欠きの場合も同様にしてぼね定数 $K_{3}$ を導 くことができる。その結果を用いて，ばね定数についてパロ ス流の近似值 $K_{3 \mathrm{P}}$ を求めると,

$$
\frac{1}{K_{3 P}}=\frac{20}{E R^{3}(2 \beta)^{7 / 2}}=\frac{20 R^{1 / 2}}{E t_{C}^{7 / 2}}
$$

\section{3. 各種条件における数値的検討}

三種の切久き形態に対する近似值 $K_{1 \mathrm{P}}$ 及び $K_{3 \mathrm{P}}$ について, それぞれの相対偏差率, $\left(K_{1 \mathrm{P}}-K_{1}\right) / K_{1}$ 及び $\left(K_{3 \mathrm{P}}-K_{3}\right) / K_{3}$ を考える。図 2 に $\beta \leqq 0.2$ についての結果を示す。パラメータ として, 円弧半角 $\theta_{\mathrm{m}}$ を 4 通りに変えている。その内, $\theta_{\mathrm{m}}=$ $90^{\circ}$ は円弧中心 $\mathrm{O}$ がくびれ部分以外の部材表面の延長線上 にある場合である。 $K_{2 \mathrm{P}}$ についての相対偏差率は $K_{1 \mathrm{P}}$ の場合 にほぼ等しいと考えられる。

図 2 によると, 近似度は全体としてかなり良好であると言 える。 $\beta$ が小さいほど, すなわちくびれ部分の厚さの割合が 小さいほど両者間の差異は小さい。また, 両者間の差異は環 状切欠きの場合のほうが小さいようである。 $\theta_{\mathrm{m}}$ が及ぼす影響 があり，特にそれが $30^{\circ}$ の場合，他の場合より差異がかなり 大きくなっている。 $\beta$ が同じでも, $\theta_{\mathrm{m}}$ が小さいのは, 切欠き の $\mathrm{x}$ 軸方向（図 1 参照）幅が大きく取られる場合である。 $\theta_{\mathrm{m}}$ を $60^{\circ}$ 以上とし, $\beta$ が 0.1 程度以下であれば，数パーセント 以下の差異と見られ，十分の近似度があると言えるのではな いかと思う。

次に設計例として, 表 1 に示す条件の両側切欠き形ヒンジ のモーメント $\mathrm{M}$ とたわみ角 $\alpha$ の関係を式(2), 式(3)及び有限 要素法により求めて比較する。図 3 に有限要素モデルを示す。

Table 1 Design conditions for a hinge with both sides cutouts

$$
\begin{aligned}
& \text { Material : phosphor bronze } \\
& E=120 \mathrm{GPa}, \quad G=43 \mathrm{GPa}, \mathrm{v}=0.33, \quad h_{\mathrm{D}}=4.5 \mathrm{~mm}, \\
& b_{\mathrm{D}}=8 \mathrm{~mm}, \quad t_{\mathrm{D}}=0.5 \mathrm{~mm}, \quad R=2 \mathrm{~mm}, \quad \theta_{\mathrm{m}}=90^{\circ}
\end{aligned}
$$

この場合は $\beta=0.125$ である。図 2 から, 式(2)と式(3)による 結果がほぼ合致することは予想されるが, 有限要素法による 結果も他とよく合っており，上述の解析は妥当であると思わ れる。

\section{4. 結 言}

・ 弧状切欠きをもつ弾性ヒンジ 3 種のばね定数を解析し， パロス等の式の導出過程を推定した。・パロス等の式の近似 度を検討し，くびれ部の厚さ割合が小さいほどそれが十分に 高いことを示した。・有限要素解析も行って本報の解析が妥 当と思われることを述べた。

貴重な情報を教示頂いた信州大学, 深田茂生教授に感謝す る。

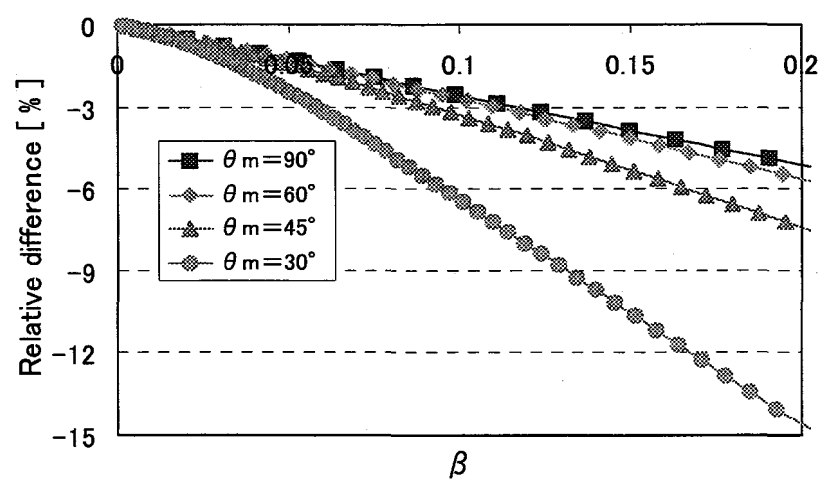

(a) Both sides cutouts

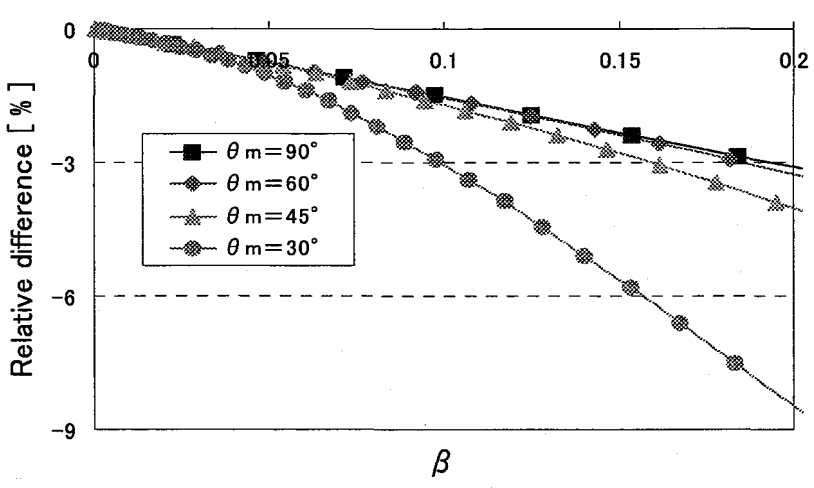

(b) Circular cutout

Fig.2 Relative differences brought by Paros's approximations

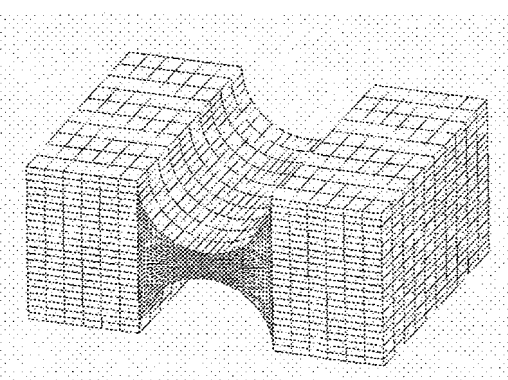

Fig.3 Appearance of a FEM model (9430 elements)

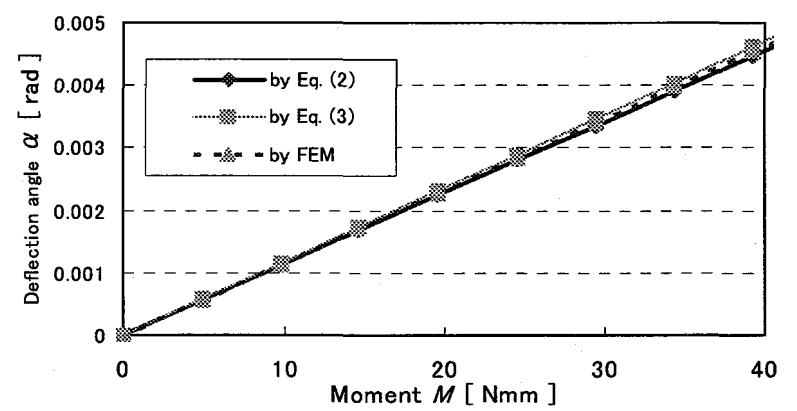

Fig.4 Graphic expressions about deflection feature obtained from 3 different methods (object: the hinge specified in Table 1)

\section{参考文献}

(1) J.M.Paros, L.Weisbord: How to design FLEXURE HINGES, Machine Design, Nov. 25, 1965, p151.

(2) 森口, 宇田川, 一松 : 数学公式 I, 岩波, 1965, p80. 